\title{
VIII Ogólnopolska Konferencja Turkologiczna organizowana w Krakowie w dniach 27-28 kwietnia 2017 roku
}

\author{
Piotr Nykiel \\ Uniwersytet Jagielloński w Krakowie, Wydział Filologiczny \\ Instytut Orientalistyki, Katedra Turkologii
}

\begin{abstract}
Summary: This is a brief announcement to inform the readers about the upcoming $8^{\text {th }}$ Conference of Polish Turkologists organized by the Chair in Turkish Studies of the Jagiellonian University in Kraków and invite them to take part in it. The conference is planned to be held on April 27-28, 2016.
\end{abstract}

Keywords: Conference of Polish Turkologists, Chair in Turkish Studies of the Jagiellonian University in Kraków, Włodzimierz Zajączkowski

Katedra Turkologii Uniwersytetu Jagiellońskiego w Krakowie organizuje w dniach 27-28 kwietnia 2017 VIII Ogólnopolską Konferencję Turkologiczną.

Będzie to już kolejne z cyklicznych spotkań polskich naukowców, odbywających się rotacyjnie od 2007 roku w ośrodkach turkologicznych w Krakowie, Poznaniu i Warszawie. Tym razem partnerami organizacyjnymi i współgospodarzami przedsięwzięcia będą także Wydział Historyczny Uniwersytetu Jagiellońskiego i Koło Naukowe Turkologów UJ.

Omawiane wydarzenie upamiętniać będzie 35. rocznicę śmierci wybitnego krakowskiego turkologa prof. Włodzimierza Zajączkowskiego (1914-1982), organizatorzy liczą więc na to, że wśród wystąpień nie zabraknie także tych 
poświęconych życiu i osiągnięciom naukowym tego znamienitego polskiego Karaima. Niemniej jednak, wzorem poprzednich edycji konferencji, spodziewane są referaty poruszające pełen wachlarz szeroko pojętej tematyki turkologicznej, czyli: językoznawstwo tureckie/turkijskie, nauczanie języków turkijskich, literatura i historia ludów tureckich, etnologia, zagadnienia politologiczno-społeczne związane ze światem tureckim i inne.

Do udziału w konferencji zaproszeni zostali przede wszystkim pracownicy naukowo-dydaktyczni, lektorzy i doktoranci wspomnianych wyżej trzech polskich ośrodków turkologicznych. Tradycyjnie organizatorzy zwrócili się też jednak do przedstawicieli innych dyscyplin naukowych, którzy z niemałym powodzeniem zajmują się w swych badaniach różnorodnymi zagadnieniami związanymi ze światem tureckim.

Ogólnopolskie Konferencje Turkologiczne cieszą się już od dziesięciu lat niesłabnącym zainteresowaniem środowiska naukowego i studentów turkologii w Polsce, ponieważ stanowią dla nich jedyną tego rodzaju platformę wymiany wiedzy, doświadczeń i wzajemnych inspiracji. Dzięki interdyscyplinarnej formule konferencji badacze zyskują nie tylko możliwość podzielenia się informacjami o zagadnieniach, którymi się aktualnie zajmują, ale także wzajemnych konsultacji w zakresie wiedzy wybiegającej poza obszar ich wąskich specjalizacji.

Termin zgłaszania chęci wygłoszenia referatu na VIII Ogólnopolskiej Konferencji Turkologicznej upływa 1 stycznia 2017. Zachęcamy gorąco wszystkich zainteresowanych do udziału w niej także w charakterze słuchaczy. Wszelkie pytania można kierować do sekretarza konferencji dr. Piotra Nykiela (piotr.nykiel@uj.edu.pl). 